\title{
Transisi Penggolongan Ganja dalam Perjanjian Pengendalian Narkoba PBB : Langkah Legalisasi
}

\author{
Nevy Rusmarina Dewi ${ }^{*}$, Melina Nurul Khofifah² \\ 1-2Institut Agama Islam Negeri Kudus, Jl. Ngembalrejo-Conge, Kudus \\ *Corresponding Author E-mail: nevyrusmarina@gmail.com
}

\begin{abstract}
This study aims to analyze the change in the status of marijuana or merijuana which was previously categorized as a dangerous psychotropic substance and is strictly limited to being less dangerous. With the pressure from various parties and the increasing use of marijuana in the medical field, WHO prompted WHO to change its attitude towards marijuana. This paper uses qualitative research methods by describing the results of research using descriptive and argumentative words to explain a phenomenon. Meanwhile, the data source used is secondary data. Derived from literature studies taken from books, journals, and online media such as websites. From the research results, it was found that the legalization of marijuana has been supported by more than half of the countries that are members of the committee. Even though marijuana has been legalized, the United Nations does not immediately free the circulation of marijuana, because there are still rules from the drug control agreement that are still being considered. Marijuana status is not fully legalized, but transferred to Group II.
\end{abstract}

Keywords: legalize, marijuana, UN Drug Control Treaties

\begin{abstract}
ABSTRAK
Penelitian ini bertujuan menganalisis tentang perubahan status ganja atau merijuana yang sebelumnya dikategorikan sebagai zat psikotropika berbahaya dan sangat dibatasi menjadi lebih tidak berbahaya. Dengan adanya desakan dari berbagai pihak dan peningkatan penggunaan ganja dalam bidang medis mendorong WHO untuk mengubah sikapnya terhadap ganja. Tulisan ini menggunakan metode penelitian kualitatif dengan mendeskripsikan hasil penelitian menggunakan kata-kata deskriptif dan argumentatif untuk menjelaskan suatu fenomena. Sedangkan sumber data yang digunakan adalah data sekunder. Berasal dari studi pustaka yang diambil dari buku, jurnal, dan media daring seperti website. Dari hasil penelitian, didapati bahwa pelegalan ganja telah didukung lebih dari setengah negara yang tergabung dalam komite. Meskipun ganja telah dilegalkan, namun PBB tidak serta merta membebaskan peredaran ganja, sebab masih ada aturan dari perjanjian pengendalian narkoba yang tetap diperhatikan. Status ganja bukan dilegalkan sepenuhnya, tapi dipindah ke Golongan II.
\end{abstract}

Kata Kunci: ganja, legalisasi, perjanjian pengendalian narkoba

\section{PENDAHULUAN}

Tulisan ini bermaksud untuk mengkaji lebih jauh mengenai perubahan status ganja dari golongan IV psikotropika, dengan lebih menekankan untuk mencari penyebab pengubahan tersebut. Marijuana atau ganja termasuk ke dalam zat narkotika yang diatur secara ketat oleh UN Drug Control Treaties. Zat ini mengandung senyawa yang dapat mempengaruhi kerja pikiran seseorang (sebagaimana golongan psikoaktif) seperti tetrahidrokannabinol atau THC, serta senyawa aktif lainnya seperti cannabidiol atau CBD yang tidak menimbulkan efek pada pikiran (CDC, 2018). Sebenarnya, ganja dan narkoba telah lama digunakan oleh umat manusia sebagai sarana ritual persembahan, bahan makanan dan obat-obatan.

\footnotetext{
* Copyright (c) 2021 Nevy Rusmarina Dewi et.al

This work is licensed under a Creative Commons Attribution-ShareAlike 4.0 International License.
} 
Ganja sering digunakan sebagai obat bagi orang dengan gangguan mental atau sebagai obat anestesi karena efek penenang yang dihasilkan. Namun, zat ini dapat menyebabkan kecanduan meskipun dengan jumlah yang sangat kecil. Lama-kelamaan, manusia mulai menyalahgunakan narkoba. Sehingga dibutuhkan instrumen internasional yang dapat mengatur peredaran narkoba agar tidak merugikan masyarakat.

Perjanjian internasional ini, baik dalam skala besar ataupn kecil akan turut mempengaruhi pelaksanaan hak dan kebebasan individu, termasuk dalam hal konsumsi ganja. Ada tiga perjanjian yang menjadi acuan utama hukum internasional untuk penagakan peredaran dan konsumsi narkotika, yaitu Konvensi Tunggal 1961 tentang Narkoba (the 1961 Single Convention), Konvensi Psikotropika 1971 (the 1971 Convention on Psychotropic Substances), dan Konvensi 1988 Melawan Perdagangan Gelap Narkotika dan Psikotropika (the 1988 Convention Against Illicit Traffic in Narcotic Drugs and Psychotropic Substances). Ketiga perjanjian ini berlaku legal binding, artinya berlaku mengikat bagi setiap negara yang meratifikasinya dan wajib untuk menerapkan kebijakan yang ditetapkan dalam konvensi. Termasuk didalamnya tidak diperbolehkan untuk melegalkan ganja dan zat narkotika lain dengan alasan selain medis.

Setengah abad berlalu setelah disahkannya perjanjian penanganan narkoba. Perkembangan pengetahuan telah membuat masyarakat terbuka pada dampak positif ganja sebagai obat-obatan. Beberapa negara telah mulai membuka negaranya untuk melegalkan ganja, seperti Uruguay sebagai negara pertama yang melegalkan ganja, Kalifornia, Kanada, Inggris, dan beberapa negara lain. Terlebih, di masa pandemi terjadi peningkatan besar dalam hal konsumsi ganja. Masalah kesehatan mental akibat isolasi dan pembatasan berskala besar membuat banyak individu bergantung pada obat jenis psikotropika yang satu ini. Seperti hasil penelitian dari Journal of Addictive Diseases yang mengungkapkan bahwa ganja telah digunakan sebagai solusi menghadapi masa sulit pandemi. Berdasarkan penelitian tersebut, penggunaan ganja medis meningkat tajam selama pandemi untuk keperluan penyembuhan hingga rata-rata penggunaannya meningkat mencapai 91 persen (Earlenbaugh, 2020). Selain itu, sebuah situs jual beli ganja daring, Ganja Goddess di California, mendapati bahwa pada masa pandemi terjadi peningkatan konsumsi hingga dua kali lipat (Dorbian, 2020). Di Indonesia juga terjadi peningkatan aktivitas peredaran ganja ilegal. Seperti usaha penyelundupan ganja seberat 173 kilogram di Jakarta Barat yang dikirimkan dari Mandailing Natal (Debora, 2020). Serta BNN Jawa Tengah yang selama 2020 menangani 21 kasus dengan 40 berkas perkara kasus narkotik dan 40 tersangka. Dengan rincian barang bukti yang disita 1,57 kilogram sabu, 12,5 kilogram ganja, 561 butir ekstasi, 79 butir permen THC, dan 6 ampul THC cair (Utama, 2020).

Dengan meningkatnya konsumsi ganja untuk kesehatan, beberapa negara mulai mengusulkan pelegalan ganja kepada Perserikatan Bangsa Bangsa (PBB). Akhirnya pada 2 Desember 2020, UN's Commission on Narcotic Drugs (CND) menyatakan menerima proposal untuk menghapus ganja dari golongan IV dalam Konvensi Tunggal. Namun demikian, pencabutan ini bukan berarti PBB telah secara total menganggap ganja sebagai obat-obatan legal. Pelonggaran akses ganja hanya akan diberikan untuk kebutuhan kesehatan dan ilmu pengetahuan dengan tetap menggunakan aturan yang disesuaikan oleh komisi (UN News, 2020).

Penyetujuan rekomendasi ini akan membawa dampak secara global, begitupun bagi Indonesia sebagai salah satu negara yang meratifikasi konvensi tentang narkotika. Meskipun pada akhirnya setiap negara peserta tetap menentukan sikapnya terhadap pengklasifikasian ganja secara nasional. Namun kebanyakan negara akan merujuk pada konvensi yang berlaku internasional ini (Susanti, 2020). Sedangkan Indonesia masih dimungkinkan untuk perundingan, data mengungkapkan bahwa kasus 
peredaran, pemakaian, dan penanaman ganja telah menjadi masalah yang gawat. Data dari press release Badan Narkotika Nasional 2019 mengungkapkan bahwa jumlah ganja yang ditangkap mencapai 1,5 Ton (1.563.417,02 gram). Jumlah ini membuat ganja menjadi salah satu bahan aktif yang paling banyak disalahgunakan secara illegal di Indonesia (BNN, 2019).

Studi mengenai langkah legalisasi ganja masih menjadi perdebatan dari beberapa penelitian terdahulu seperti pada penelitian Parama dkk (2015) adanya organisasi yang memperjuangkan legalisasi ganja dan menyatakan bahwa ganja tidak seharusnya dimasukkan kedalam golongan berbahaya seperti kokain,sabu-sabu dan putaw, Lokollo dkk (2020) menyatakan bahwa ganja perlu dimasukan kedalam Narkotika Golongan II atau Golongan III supaya dapat digunakan sebagai bahan medis, dan Putra (2014) menyatakan indonesia memiliki urgensitas legalisasi hemp ( ganja industry ). Penelitian ini meneruskan dari beberapa penelitian terdahulu dengan melihat bagaimana transisi legalisasi ganja pada UN Drug Control, Berbagai desakan dan dukungan mulai menyuarakan legalisasi ganja baik dari organisasi resmi maupun individu pemanfaatan ganja dengan baik menjadi alasan utama legalisasi ganja selain itu penelitian ini juga berupaya untuk menjawab pertanyaan bagaimana perkembangan ganja sebagai salah satu obat dengan senyawa psikotropika dalam perjanjian pengendalian narkoba PBB.

\section{METODOLOGI PENELITIAN}

Penelitian ini menggunakan metode penelitian kualitatif (Creswell, 2015), yaitu dalam memperoleh data tidak berupa angka-angka, melainkan serangkaian kata-kata deskriptif untuk memahami dan menafsirkan proses perubahan status ganja. Adapun sumber data yang digunakan dalam tulisan ini adalah data sekunder yang berasal dari studi pustaka dengan sumber berupa buku, jurnal, dan website yang memiliki kesamaan topik mengenai perubahan atau legalisasi ganja.

\section{HASIL DAN PEMBAHASAN}

\section{PERJANJIAN INTERNASIONAL}

Pasca perang dunia kedua, negara-negara telah menyadari bahwa peperangan bukan lagi menjadi bentuk utama dari hubungan internasional. Banyak negara kemudian menyadari bahwa pemenuhan kebutuhan dan pencapaian cita-cita tujuan nasional suatu negara harus berhubungan dengan negara lain. Perkambangan dunia pun menjadi semakin dinamis, dan permasalahan ang dihadapi oleh negara-negara menjadi semakin kompleks. Sehingga dibutuhkan suatu bentuk hubungan supra nasional untuk mengatasi masalah bersama tersebut. Hubugnan tersebut akhirnya tertuang dalam suatu perjanjian internasional yang bersifat mengikat bagi semua negara yang tergabung. Banyak nama untuk menyebut treaty, seperti perjanjian, pakta, konvensi, atau traktat.

Secara khusus, perjanjian internasional dijabarkan dalam Konvensi Wina tahun 1969 atau Vienna Convention on the Law of Treaties 1969. Pada konvensi ini diberi arti bahwa:

"treaty means an international agreement concluded between state in written form and governed by internasional law, wether embodied in a single instrument or in two or more related instruments and whatever its particular designation" (Aust, 2018)

(Persetujuan/pakta adalah perjanjian internasional yang dibuat antara negara dalam bentuk tertulis dan diatur oleh hukum internasional, baik yang tertuang dalam satu instrumen atau dalam dua atau lebih instrumen terkait dan apapun peruntukannya) 
ada beberapa pendapat yang menyatakan pengertian perjanjian internasional. Seperti diungkapkan oleh Kusumaatmaja dan Agoes perjanjian internasional adalah perjanjian yang dibuat oleh masyarakat global dari berbagai bangsa untuk mengatur sebab akibat hokum tertentu. Sedangkan Mauna mengartikan perjanjian internasional sebagai kehendak dan persetujuan antar negara yang dinyatakan sebagai instrument hokum yuridis untuk mencapai tujuan bersama. Setiap negara di dunia boleh untuk mengadakan perjanjian internasional. Ketika sebuah negara telah memutuskan untuk menjadi anggota perjanjian internasional maka negara itu memiliki hak dan kewajiban sesuai konsekuensi yang dibebankan oleh perjanjian. Disinilah tampak bahwa perjanjian internasional akan mempengaruhi arah kebijakan suatu negara (Situngkir, 2019).

Telah dirangkum oleh John O’Brian, ada beberapa prinsip yang menjadi dasar bagi terlaksananya perjanjian internasional:

1. Perjanjian internasional lahir akibat adanya persetujuan

2. Berlakunya perjanjian internasional adalah keputusan dari negara yang bermaksud menyetujuinya

3. Jika perjanjian internasional memuat soal kebiasaan, maka setiap negara yang terikat pada perjanjian internasional wajib untuk mengadopsinya

4. Bagi negara yang bukan peserta perjanjian masih diwajibkan untuk mentaati perjanjian internasional sebagai akibat dari kebiasaan

5. Perjanjian international yang bersifat multilateral umumnya dibentuk dibawah International Law Commision dengan tujuan untuk menciptakan hokum internasional yang progresif (Situngkir, 2018)

Maalah yang menjadi cikal bakal lahirnya perjanjian internasional adalah hal yang menyangkut masyarakat secara global. Seperti perihal narkoba yang masalahnya tidak hanya menimpa satu negara, melainkan banyak negara karena peredarannya tidak terkontrol. Oleh karena itu, negara-negara membentuk konvensi untuk mengatur narkoba secara global. Sebelum lahirnya UN Drug Control Treaties, beberapa perjanjian internasioal sudah pernah dibuat. Perjanjian pertama tercatat pada 16 Februari 1909 ditandatangani di Shanghai, Cina, yaitu Final Resolutions of the International Opium Commission. Adanya perjanjian ini untuk mengatur peredaran opium di Cina pada masa kolonial. Perjanjian-perjanjian serupa terus bergulir hingga tahun 1953 namun keberadaannya untuk mengatur salah satu atau beberapa zat narkoba, dan bukan untuk mengatur keseluruhannya dalam satu dokumen. Untuk itu, Liga Bangsa-Bangsa merangkum keseluruhan perjanjian internasional tersebut dalm satu instrument pada 1961 yang kemudian dinamai Konvensi Tunggal (Single Convention) (Sinha, 2001).

Adapun, lahirnya dua konvensi setelah Konvensi Tunggal 1961 adalah untuk menjawab perkembangan penggunaan dan peredaran narkoba yang sebelumnya belum dicantumkan dala konvensi tunggal. Seperti alasan dibentuknya Konvensi tentang Psikotropika 1971 yaitu maraknya penggunaan zat psikotropika seperti amfetamin, barbiturate, dan LSD. Ada paling banyak di negara Barat, zat psikotropika ini dianggap meiliki dampak negative bagi kesehatan dan kehidupan social dengan banyaknya orang meninggal akibat overdosis dan kekerasan yang dipicu efek dari zat tersebut (Sinha, 2001). Sedangkan lahirnya perjanjian ketiga, the 1988 Convention Against Illicit Traffic in Narcotic Drugs and Psychotropic Substances dilatari oleh pesatnya konsumsi narkoba golongan IV menurut Konvensi Tunggal untuk keperluan non medis. Sehingga dibutuhkan langkah komprehensif untuk menghentikan peredaran dengan melarang pasar gelap (Primer, 2015).

Narkotika dan zat psikotropika (secara kolektif disebut sebagai "obat-obatan terlarang") diatur oleh tiga perjanjian Perserikatan Bangsa-Bangsa (PBB) yang membentuk pengendalian narkoba internasional: Konvensi Tunggal 1961 tentang Narkoba (the 1961 Single Convention), Konvensi Psikotropika 1971 (the 1971 Convention on Psychotropic Substances), dan Konvensi 1988 Melawan 
Perdagangan Gelap Narkotika dan Psikotropika (the 1988 Convention Against Illicit Traffic in Narcotic Drugs and Psychotropic Substances). Pada intinya, perjanjian ini bertujuan untuk membatasi penggunaan narkoba dengan meminta negara anggota untuk mengkriminalisasi kepemilikan, budidaya, produksi, impor, penjualan, dan distribusi obat-obatan terlarang untuk tujuan non-medis dan non-ilmiah.

Pada Juli 2018, terdapat 186 Pihak pada Konvensi Tunggal, 184 pada Konvensi Psikotropika, dan 190 pada Konvensi Perdagangan. Terlepas dari partisipasi yang hampir universal, perjanjian ini sering dikritik sebagai produk dari masa lampau dan tidak sejalan dengan norma-norma kontemporer dan penelitian kesehatan masyarakat. Dengan secara eksplisit mengizinkan negara anggota untuk mengadopsi kebijakan yang ketat atau keras tampa memperhatikan hak asasi, seperti penerapan hukuman mati untuk pelanggaran terkait narkoba. Perjanjian ini juga telah disinyalir menjadi fasilitas pelanggaran sistematis hak asasi manusia universal dengan dalih perjanjian (Habibi \& Hoffman, 2017).

\section{DASAR PENGENDALIAN NARKOBA INTERNASIONAL}

Sebelum disuarakan oleh Liga Bangsa-Bangsa, upaya untuk melawan penggunaan narkoba dan perdagangan manusia secara internasional sudah dimulai dari Konferensi Shanghai 1909 yang diselenggarakan oleh kekuatan kolonial Eropa untuk menangani penggunaan opium di Cina. Selanjutnya Konvensi Opium Internasional 1912, menjadi landasan bagi peluncuran serangkaian perjanjian tentang pengendalian narkoba. Konvensi ini juga berperan sebagai dasar bagi pengendalian narkoba internasional kontemporer. Pada saat draf akhir Konvensi Tunggal disepakati pada tahun 1961, perjanjian ini telah menggabungkan beberapa dekade perjanjian pengendalian narkoba menjadi satu set aturan yang dikelola oleh PBB (Habibi \& Hoffman, 2017).

Konvensi Tunggal dalam mengontrol obat-obatan terlarang (illicit drug) memaksa neagra-negara anggota yang meratifikasi untuk menerapkan langkah-langkah legislatif dan pengaturan dasar untuk melarang produksi, penggunaan dan perdagangan obat-obatan narkotika. Dalam pembukaannya, Konvensi Tunggal dibuat dengan memperhatikan dampak kesehatan dan kesejahteraan umat manusia. Dengan dua pertimbangan utama, yaitu bahwa penggunaan obat-obatan narkotika dalam bidang kesehataan sangat berguna untuk mengurangi rasa sakit dan tersiksa, sehingga ketersediannya harus tetap diperhitungkan, dan bahwa kecanduan terhadap narkotika dapat berujung pada kejahatan serius pada diri seseorang dan berkemungkinan besar menimbulkan masalah besar bagi lingkungan sekitarnya. PBB mengibaratkan bahwa dunia sedang berperang melawan kejahatan dalam pembukaannya dengan kalimat "conscious of their duty to prevent and combat this evil" . Karena itu konvensi tunggal dibuat sebagai dasar internasional yang mengatur pengedaran dan pemakaian narkotika (UNODC, 2013).

Perjanjian ini secara khusus tidak mendefinisikan apa yang dimaksud sebagai obat narkotika. Tapi dalam pasal 1 ayat $j$ disebutkan bahwa obat yang diatur dalam perjanjian tersebut adalah zat alami atau sintetis dalam Golongan I dan II yang dilampirkan pada Konvensi Tunggal. Golongan tersebut diklasifikasikan menurut efek terapeutik yang dirasakan dan potensi penyalahgunaan. Zat yang termasuk dalam golongan I harus tunduk pada semua ketentuan pembatasan dalam Konvensi Tunggal. Zat dalam golongan II, III, dan sebagian kecil golongan IV mendapat beberapa ketentuan pembebasan berdasarkan konvensi. Sedangkan golongan IV, sama halnya dengan Golongan I, diharuskan tunduk pada semua ketentuan dan ketentuan tambahan. Ekstrak tanaman ganja, termasuk minyak, terdaftar ganda dalam golongan I dan IV (UNODC, 2013).

Sebagai upaya mempertahankan kontrol atas pasar obat-obatan terlarang, Konvensi Tunggal berisi ketentuan untuk sistem perkiraan dan kuota yang diperlukan bagi obat-obatan narkotika. Negara anggota harus memberikan informasi tahunan mengenai jumlah obat yang diperlukan untuk penggunaan yang 
sah kepada Badan Pengawasan Narkotika Internasional (International Narcotics Control Board/INCB), badan pemantau independen. Total estimasi ini dihitung terhadap total produksi legal obat. Statistik tahunan tentang produksi atau pembuatan obat, penggunaan obat untuk pembuatan obat lain dan zat tertentu, konsumsi, dan stok obat juga harus disediakan.

Dengan inisiatif yang dipimpin pemerintah AS, Konvensi Tunggal diubah pada tahun 1972 melalui Protocol Amending the Single Convention on Nacotic Drugs 1961 Protokol yang Mengamandemen Konvensi Tunggal Narkotika 1961 (Protokol 1972). Dampak utama dari perubahan tersebut adalah bertambahnya mandat INCB untuk mencegah orang-orang terlarang. pembudidayaan, produksi dan pembuatan, peredaran gelap, dan penggunaan narkoba. Ketentuan tentang pencegahan penggunaan narkoba juga diubah dengan memasukkan pengobatan, pendidikan, perawatan setelah perawatan, rehabilitasi dan reintegrasi sosial sebagai alternatif atau pengganti dari keharusan. Hal ini diambil meminjam dari ketentuan serupa yang muncul satu tahun sebelumnya dalam Konvensi Psikotropika (UNODC, 2013).

Konvensi Psikotropika hadir sebagai reaksi atas munculnya obat-obatan sintetik, seperti amfetamin, barbiturat, dan benzodiazepin. Mengingat zat-zat tersebut sebelumnya tidak digolongkan dalam Konvensi Tunggal. Beberapa ketentuan juga diulang kembali untuk zat psikotropika, termasuk pencatatan zat psikotropika dalam empat golongan dalam Konvensi Psikotropika. Tetrahydrocannabinol (THC) sebagai bahan aktif utama dalam ganja, terdaftar dalam Golongan II (Habibi \& Hoffman, 2017).

\section{ARGUMENTASI TENTANG PELEGALAN GANJA}

Sub bab ini akan terfokus pada usaha pelegalan ganja oleh kelompok-kelompok yang menyatakan bahwa ganja tidak sepatutnya dikriminalisasi. Sebaliknya, ganja sebagai konsumsi individu dan medis harus didukung. Salah satu pendapat mengungkapkan, larangan ganja belum terbukti menjadi strategi yang efektif untuk mengurangi meluasnya pasar gelap atau bahaya kesehatan akibat ganja. Sebaliknya, pelarangan ganja telah membebani sistem peradilan pidana, menghasilkan dampak sosial dan kesehatan masyarakat yang sangat negatif, dan menciptakan pasar kriminal yang mendukung kejahatan terorganisir, kekerasan, dan korupsi. Berdasarkan alasan-alasan tersebut, akhirnya kebijakan pelegalan pasar ganja berkambang menjadi pilihan kebijakan yang semakin menarik untuk dipertimbangkan oleh negaranegara. Ketegangan yang terjadi antara golongan pendukung dan penolak ganja saat ini munculkarena adanya keputusan untuk menempatkan ganja di bawah pengawasan ketat sebagai bagian dari landasan hukum kontemporer, Konvensi Tunggal 1961. Melalui pengaturan ini, ganja dan zat lain yang terdaftar hanya boleh diproduksi, manufaktur, ekspor, impor, distribusi, perdagangan, digunakan, dan dimiliki dalam skala sangat ekslusif untuk tujuan medis dan ilmiah (UNODC, 2013).

Ganja, sebagai obat terlarang (illicit drug) yang paling banyak digunakan di dunia, dikategorikan dalam Konvensi Tunggal bersamaan golongannya dengan kokain dan heroin. Namun keputusan yang diambil lebih dari 50 tahun lalu ini dinilai sebagian besar pihak tidak memiliki pertimbangan bukti ilmiah yang tersedia mengenai risiko kesehatan relatif. Sekarang, konvensi mengenai pengerndalian narkotika menjadi perjanjian internasional yang paling banyak mengikat negara-negara di dunia. Perjanjian yang berlaku universal ini, bagaimanapun, telah melewatkan beberapa aspek dalam perkembangannya. Kondisi negara penandatangan Konvensi Tunggal sudah berbeda dari saat pertama perjanjian dibuat. Perjanjian pengendalian narkoba dibuat dengan menggabungkan beberapa perjanjian internasional tentang hal yang sama sejak 1912. Pada masa itu, narkoba masih menjadi barang langka dan sifatnya marginal. Itu sebabnya, hanya sebagian kecil negara yang paham akan narkoba dan bisa mengarahkan kebijakan ke arah yang mereka inginkan dan lebih berorientasi pada kebijakan pelarangan. Namun 
sekarang, beberapa penelitian telah mengungkapkan potensi ganja digunakan dalam bidang medis dan ilmu pengetahuan sehingga lebih memberi gambaran baru bagi dunia internasional tentang ganja (Bewley-Taylor et al., 2016). Beberapa penelitian di Amerika Serikat menunjukkan bahwa ganja dapat bermanfaat bagi pengobatan seseorang. Termasuk didalamnya berpotensi sebagai obat nyeri kronis, mual, muntah akibat kemoterapi, dan gejala multiple sclerosis yang aman digunakan. Tinjauan kesehatan ini yang membuat beberapa negara mulai melonggarkan ketentuannya bagi ganja pada level individu untuk pengobatan. Kehadirannya sebagai golongan I dalam Konvensi Tunggal dinilai akan menghambat pemanfaatan ganja sebagai obat (Drug Policy Alliance, 2019).

Satu perdebatan yang menarik perhatian media utama adalah apakah ganja meningkatkan risiko penyakit psikotik, dan ada juga fokus media pada sejauh mana ganja mengarah pada penggunaan dan kecanduan narkoba lainnya. Pertanyaan lain yang diperdebatkan adalah apakah ganja memiliki khasiat obat yang meringankan kondisi seperti epilepsi, multiple sclerosis (MS) dan nyeri kronis. Dalam beberapa tahun terakhir, Uruguay, Kanada, dan beberapa negara bagian AS telah melegalkan ganja, meskipun dalam banyak kasus penjualan diatur secara ketat. Perubahan juga terlihat di Eropa, dengan negara-negara seperti Portugal dan Norwegia mendekriminalisasi penggunaan ganja untuk keperluan pribadi. Di Swedia, liberalisasi cenderung menjadi isu yang diangkat oleh sayap pemuda partai politik.

Ganja diklasifikasikan sebagai zat narkotika di bawah Konvensi Tunggal PBB tentang Narkotika. Ini berarti bahwa obat tersebut hanya boleh digunakan untuk tujuan ilmiah dan medis (sebagai pengobatan yang disetujui) dan dilarang untuk dimiliki, dibudidayakan, dan dijual. Sebagian besar negara di dunia telah meratifikasi konvensi tersebut, yang artinya harus dimasukkan ke dalam perundang-undangan nasionalnya. Namun, bentuk undang-undang dan cara penerapannya sangat bervariasi dari satu negara ke negara lain. Di Belanda misalnya, telah lama legal untuk menjual ganja di 'kedai kopi', tetapi penanaman dilarang, seperti halnya kepemilikan dalam jumlah besar. Di Denmark, perdagangan ganja dulunya diizinkan di Christiania, tetapi selama 15 tahun terakhir, kebijakan tersebut telah berubah, dengan fokus aktif pada pemberantasan perdagangan narkoba. Ganja dilarang di bawah hukum federal di AS, tetapi sejumlah negara bagian telah melegalkannya dengan berbagai cara pengaturan. Swedia dan banyak negara lain memiliki undang-undang yang membatasi kepemilikan dan konsumsi ganja pribadi. Namun, kepemilikan ganja dalam jumlah kecil untuk penggunaan pribadi dapat dikenai hukuman ringan, biasanya denda, sementara perdagangan ganja dalam jumlah besar dapat dituntut sebagai kejahatan narkoba yang serius, biasanya mengakibatkan hukuman penjara.

Oleh karena itu, perdebatan tentang 'legalisasi' ganja perlu lebih terfokus untk menjawab pertanyaan bagaimana hukum mengatur bagian-bagian berbeda dari rantai ganja, dari budidaya dan produksi hingga penggunaan pribadi, dan hukuman apa yang berlaku ketika hukum dilanggar. Semua negara memiliki beberapa bentuk regulasi, seperti kontrol terhadap penanaman, batasan usia dan tempat penjualan tertentu. Sedangkan penggunaan kata dekriminalisasi dirasa kurang tepat karena maknanya yang berarti menormalkan ganja dalam kehidupan sehari-hari untuk konsumsi probadi, bukan untuk keperluan pengobatan. Proses dekirminalisasi menanamkan pemahaman bahwa ganja tidak salah untuk dikonsumsi siapapun dan untuk tujuan apapun. Kata ini juga di rasa salah karena adanya temuan hubungan antara laporan cidera dan keracunan akibat ganja dengan dekriminalisasi ganja di beberapa negara bagian di Amerika Serikat. Seperti di Colorado, dilaporkan terjadi penambahan kasus cidera dan keracunan, kecelakaan di jalan raya, dan overdosis seiring dengan dekriminilisasi ganja (Danielsson et al., 2019). 


\section{PENGUBAHAN STATUS GANJA}

Dalam meninjau serangkaian rekomendasi Organisasi Kesehatan Dunia (WHO) tentang ganja dan turunannya, Komisi Narkotika (Commission on Narcotic Drugs/CND) memusatkan perhatian pada keputusan untuk menghapus ganja dari Golongan IV dari Konvensi Tunggal 1961 tentang Narkotika. Dalam konvensi ini, ganja terdaftar di samping opioid spesifik yang mematikan dan membuat ketagihan, termasuk heroin, yang dikenal memiliki sedikit atau bahkan tidak ada tujuan terapeutik. 53 Negara Anggota CND, badan pembuat kebijakan obat pusat PBB, memilih untuk menghapus ganja dari golongan itu. Sebelumnya, ganja telah ditempatkan di golongan tersebut selama 59 tahun yang mana mengharuskan langkah-langkah kontrol paling ketat berlaku, bahkan umumnya melarang penggunaannya untuk tujuan medis. Melalui hasil pungutan suara pada Reconvened 63 ${ }^{\text {rd }}$ Session Comision on Narcotics Drug dengan hasil 27 setuju, 25 menentang, dan satu abstain, CND telah membuka pintu untuk mengenali potensi pengobatan dan terapeutik obat tersebut, meskipun penggunaannya untuk tujuan non-medis dan nonilmiah akan tetap ilegal, keputusan tersebut dapat mendorong penelitian ilmiah tambahan ke dalam khasiat obat tanaman (UN News, 2020).

Tabel 1. Sikap negara terhadap keputusan ganja

\begin{tabular}{ll}
\hline Sikap & Negara \\
\hline Setuju & Australia, Austria, Belgia, Kanada, \\
& Kolombia, Kroasia, Republik Crech, \\
& Ekuador, EL Savador, Prancis, Jerman, \\
& India, Italia, Jamaika, Mexico, Maroko, \\
& Nepal, Belanda, Polandia, Afrika Selatan, \\
& Spanyol, Swedia, Switzerland, Thailand, \\
& Inggris, Amerika Serikat, Uruguay \\
\hline Tidak & Afganistan, Algeria, Angola, Bahrain, \\
& Brazil, Burkina Fasco, Chile, China, Cote \\
& d'ivoire, Cuba, Mesir, Hungaria, Irak, \\
& Jepang, Kazakhstan, Kenya, Kirgistan, \\
& Libya, Nigeria, Pakistan, Peru, Rusia, \\
& Togo, Turki, Turmenistan \\
\hline Abu-abu & Ukraina \\
\hline
\end{tabular}

Sumber : UN News (2020)

Kembali pada Januari 2019, WHO meluncurkan enam rekomendasi seputar daftar ganja dalam perjanjian pengendalian obat internasional. Sementara proposal dipresentasikan untuk keputusan oleh CND pada sesi Maret 2019, banyak negara meminta lebih banyak waktu untuk mempelajari masalah tersebut dan menentukan posisi mereka. Oleh karena itu, pemungutan suara barlangsung secara intensif dan rinci selama dua tahun. Di antara rekomendasi WHO, disarankan bahwa cannabidiol (CBD) dengan Tetrahydrocannabinol (THC, zat adiktif) 2 persen atau kurang tidak boleh diatur oleh kontrol internasional. Beberapa negara ada yang menerima dan menolak (lihat tabel 1 )Negara Anggota menolak rekomendasi tersebut karena berbagai alasan, termasuk beberapa Negara Anggota dengan alasan bahwa CBD saat ini tidak berada di bawah kendali internasional dan karenanya tidak diperlukan tindakan. CBD telah mengambil peran penting dalam terapi kesehatan dalam beberapa tahun terakhir, dan memicu industri bernilai miliaran dolar.

Saat ini, lebih dari 50 negara telah mengadopsi program ganja sebagai obat, sedangkan Kanada, Uruguay dan 15 negara bagian AS telah melegalkan penggunaannya untuk rekreasional, dengan Meksiko dan Luksemburg memiliki perdebatan politik mengenai keputusan mengikutinya atau tidak. Setelah pemungutan suara, beberapa negara membuat pernyataan tentang pendirian mereka. Ekuador 
mendukung semua rekomendasi WHO dan mendesak agar produksi, penjualan dan penggunaan ganja, memiliki "kerangka peraturan yang menjamin praktik yang baik, berkualitas, inovasi dan pengembangan penelitian". Sementara itu, Amerika Serikat memilih untuk menghapus ganja dari Golongan IV Konvensi Tunggal sambil mempertahankannya dalam Golongan I, dengan mengatakan bahwa meskipun ganja dalam bidang kesehatan menunjukkan konsistensinya untuk mengarah pada kebaikan dan keamanan, penggunaannya secara berkelanjutan menimbulkan risiko signifikan terhadap kesehatan masyarakat dan harus terus dikendalikan di bawah konvensi pengawasan obat internasional. Dalam pemungutan suara, Chili berpendapat bahwa ganja memiliki hubungan dengan depresi, pengurangan kemampuan kognitif, kecemasan, dan gejala psikotik. Sedangkan Jepang menyatakan bahwa penggunaan non medis dapat menimbulkan dampak negatif kesehatan dan sosial, terutama di kalangan pemuda (UN News, 2020). Tabel 2 menunjukkan rundown suara pada rekomendasi ganja WHO (Jeager, 2020)

Tabel 2. Sikap PBB terhadap rekomendasi WHO

\begin{tabular}{lc}
\hline \multicolumn{1}{c}{ Opsi } & Keputusan \\
\hline Hapus marijuana dari golongan IV Konvensi Tunggal 1961 & Disetujui \\
\hline $\begin{array}{l}\text { Menambahkan THC dan dronabinol (THC sintetis atau yang } \\
\text { berasal dari tumbuhan) ke golongan I Konvensi 1961, jika } \\
\text { disetujui, hapus dari golongan II Konvensi 1971 }\end{array}$ & Ditolak \\
\hline $\begin{array}{l}\text { Jika rekomendasi 1 dan 2 diadopsi, tambahkan } \\
\text { tetrahydrocannabinol ke golongan I Konvensi 1961 dan jika } \\
\text { disetujui, hapus dari golongan I Konvensi 1971 }\end{array}$ & Ditolak \\
\hline $\begin{array}{l}\text { Hapus “ekstrak dan tincture ganja” dari golongan I Konvensi } \\
\text { 1961 }\end{array}$ & Ditolak \\
\hline $\begin{array}{l}\text { Tambahkan catatn kaki untuk mengklarifikasi bahwa produk } \\
\text { CBD yang engandung tidak lebih dari 0,2 persen THC tidak } \\
\text { tunduk pada control internasional }\end{array}$ & Ditolak \\
\hline $\begin{array}{l}\text { Tambahkan "persiapan yang mengandung dronabinol” ke } \\
\text { golongan III Konvensi 1961 }\end{array}$ & Ditolak \\
\hline r (2020)
\end{tabular}

Sumber : Jeager (2020)

Meskipun kesepakatan untuk melegalkan ganja seperti yang diharapkan berbagai pihak masih jauh dari kenyataan, karena masih tergolong dalam Golongan I. Namun keputusan PBB untuk mengeluarkan ganja dari golongan IV telah dianggap sebagai suatu langkah progresif bagi pihak-pihak aktivis yang mendukung pelegalan ganja (Jeager, 2020). Perlu dicatat disini, bahwa meskipun penggolongan ulang ini berlaku secara global, negara masih dipertimbangkan kedaulatannya sehingga pengaturan ganja secara lebih rinci diserahkan kembali pada negara peserta UN Drug Control Treaties. Pertimbangan kedaulatan negara untuk mengendalikan peredaran narkoba di negaranya sendiri sesuai dengan ketentuan Pasal 39 Konvensi Tunggal 1961.

Indonesia sebagai salah satu negara peserta ratifikasi berhak menentukan sikapnya tersendiri. Badan Narkotika Nasional telah menyelenggarakan konferensi pers menyatakan bahwa Indonesia masih akan terus mengkaji segi kebermanfaatan ganja. Sementara ganja masih ditempatkan pada golongan I (sangat berbahaya) dalam Undang-Undang Nomor 35 Tahun 2009 tentang Narkotika sehingga Indonesia tidak atau belum mengikuti rekomenasi PBB (Humas BNN, 2020). 


\section{SIMPULAN}

Proses transisi ganja dari golongan IV menjadi hanya golongan I masih memungkinkan untuk pengkajian lebih lanjut. Transisi ini dapat memakan banyak waktu menimbang hanya ada perbedaan dua negara dalam pemungutan suara dan masih banyak negara menolak pengklasifikasian ulang. Salah satu pertimbangan dari negara-negara penolak adalah dampak kesehatan dan social yang akan terjadi bila pelegalan ganja terjadi. Meskipun manfaat ganja medis telah diidentifikasi, namun penyalahgunaannya untuk kepentingan rekreasional akan menimbulkan kecanduan. Berdasarkan uraian diatas maka diperlukan upaya riset secara komprehensif dan berkala untuk mengetahui jalannya proses pelegalan ganja. Khususnya di Indonesia yang pada masa ini masih mengkaji. Sikap Indonesia secara tegas menolak berdasarkan Undang-Undang Nomor 35 Tahun 2009 tentang Narkotika.

\section{DAFTAR PUSTAKA}

Aust, A. (2018). Vienna Convention on the Law of Treaties 1969. In Modern Treaty Law and Practice (Vol. 1155, Issue January 1980, pp. 5-13). https://doi.org/10.1017/cbo9781139152341.005

Bewley-Taylor, D., Jelsma, M., Rolles, S., \& Walshe, J. (2016). Cannabis Regulation and the UN Drug Treaties: Strategies for Reform.

BNN. (2019). Press Release Akhir Tahun 2020. In bnn.go.id.

CDC. (2018). What is Marijuana? Cdc.Gov.

Creswell, J. W. (2015). Penelitian kualitatif \& desain riset: memilih diantara lima pendekatan. In Yogyakarta: Pustaka Pelajar.

Danielsson, A.-K., Olsson, P., \& Allebeck, P. (2019). Cannabis: Harmless Recreation or Harmful Drug. Forte.

Debora, S. T. (2020). Fakta Penyelundupan 173 Kg Ganja dari Mandailing Natal, Diselip di Antara Kedondong. Kompas.Com.

Dorbian, I. (2020). Cannabis Consumption Surges During Pandemic As Sleep Issues And Anxieties Mount, Says New Poll. Forbes.

Drug Policy Alliance. (2019). Removing Marijuana from the Schedule of Controlled Substances. Drug Policy Alliance.

Earlenbaugh, E. (2020). Medical Cannabis Use For Mental Health Increased During Covid-19 Pandemic, Study Finds. Forbes.

Habibi, R., \& Hoffman, S. J. (2017). Legalizing cannabis violates the UN drug control treaties, but progressive countries like Canada have options. In Ottawa Law Review.

Humas BNN. (2020). Hasil Voting Pada Reconvened 63rd Session Commision On Narcotics Drugs Terkait Cannabis dan Cannabis Resin. Bnn.Go.Id.

Jeager, K. (2020). United Nations Removes Marijuana From Most Strict Global Drug Category, With U.S. Support. Marijuana Moment.

Lokollo, L., Salamor, Y. B., \& Ubwarin, E. (2020). Kebijakan Formulasi Undang-undang Narkotika Dalam Legalisasi Penggunaan Ganja Sebagai Bahan Pengobatan di Indonesia. Jurnal Belo, 5(2), 1-20.

Parama, I. S., Ranteallo, I., \& Kebayantini, N. (2015). Peran Lingkar Ganja Nusantara Dalam Legalisasi Ganja. Jurnal Ilmiah Sosiologi (SOROT), 1(03), 1-12.

Primer. (2015). The UN Drug Control Conventions. Transnational Institute.

Putra, M. (2014). Kebijakan Pendayagunaan Hemp (Ganja Industri) untuk Kepentingan Industri di Indonesia. Kumpulan Jurnal Mahasiswa Fakultas Hukum, 1(1).

Sinha, J. (2001). The History And Development Of The Leading International Drug Control Conventions. Sencanada.Ca.

Situngkir, D. A. (2018). Terikatnya Negara dalam Perjanjian Inernasional. Jurnal Refleksi Hukum, 2(2).

Situngkir, D. A. (2019). Perjanjian Internasional Dan Dampaknya Bagi Hukum Nasional. KERTHA WICAKSANA: Sarana Komunikasi Dosen Dan Mahasiswa, 13(1), 19-25.

Susanti, S. (2020). PBB Hapus Ganja dari Daftar Obat Paling Berbahaya di Dunia. Okezone.

UN News. (2020). UN commission reclassifies cannabis, yet still considered harmful. UN News. 
Khazanah Hukum, Vol. 3 No. 2: 59 - 69

Transisi Penggolongan Ganja dalam Perjanjian Pengendalian Narkoba PBB : Langkah Legalisasi Nevy Rusmarina Dewi, Melina Nurul Khofifah

UNODC. (2013). The International Drug Control Conventions.

Utama, D. A. (2020). Ungkap 21 Kasus, BNN Jateng Sebut Modus Peredaran Narkoba Kian Kreatif Saat Pandemi. Merdeka.Com. 